\title{
Reseña: Guerrero, María Paz. (2018). Dios también es una perra
}

Guerrero, María Paz (2018). Dios también es una perra. Bogotá: Cajón de Sastre. 48 p. ISBN 978-958-48-4957-1

También el cinismo es de etimología perruna — kynos, can- y consiste, sin más, en un gran ojo fijo e inyectado en sangre, voyeur $\mathrm{y}$ espejo del lector que ahora inclina la nariz sobre este libro y se refleja. Dios no ha muerto (Nietzsche, 1882), Dios no es una prostituta (Bataille, 1941), Dios también es una perra ilustrada y algo indispuesta como todos nosotros, conciudadanos de una exhausta, aunque muy joven, metrópoli contemporánea.

A la manera del Buhonero del reverso del Carro de heno (¿15001502?), de El Bosco, estas perras llevan en su capacho todas las desventuras, sus acciones y sus malas tentaciones, todas sus esperanzas decepcionadas, algunas alegrías también, sin duda, todo cuanto constituye el frágil fardo de una vida humana. Han envejecido, están cansadas, están solas. "La mirada está cargada de melancolía, pero la boca esboza una leve sonrisa como para decirnos que, después de todo, su lote fue como el de cualquiera y que no hay por qué dramatizar." (Gauffreteau- Sévy, 1967).

Citar: Carvajal Frankling, J. (julio-diciembre 2018). Reseña: Guerrero, María Paz. (2018), 153-164. Dios también es una perra. La Palabra, (33). doi: https://doi. org/10.19053/01218530.n33.2018.8822

\section{Juan Carvajal Franklin}

Magíster en Literatura Comparada, Universidad Autónoma de Barcelona. juancarvajalfranklin@gmail.com 
La poesía se basa en el lenguaje, en su ritmo profundo. Lo que hay entre escritura y palabra, el torbellino narrativo en el que converge la ciudad en sus clases sociales, en su habla, en su inconsciente turbio, los hechos, las personas, las cosas, el éxtasis y la vulgaridad en imágenes simultáneas, todo ello es explorado en Dios también..., más allá de los linderos de la puntuación y de las letras capitales, en un sistema de contrapesos invisibles, de aparente sencillez, pero de alta precisión lingüística.

Lejos de la provocación o de la anarquía, Dios también... es una obra construida, acabada y concluida, como quería Raymond Queneau (Calvino, I, 1992), en contra de la "inspiración”, del lirismo romántico, del culto del azar y del automatismo.

Y para entender todo mejor y para mayor abrigo, la apariencia real del libro de María Paz Guerrero, ha sido vestida con el diagrama de la danza alfabética del laberinto o diagrama de flujo mental, sobre cartulina escolar azul celeste, cosido y con bordes redondeados, e impreso en una gradación gris.

Ojee el lector en voz alta o en murmullo, algunos fragmentos del poema que juzgamos por nuestra cuenta y riesgo, una proeza. Y no decimos todo. Casi nunca lo hacemos.

"dios come jamón

Y le va a dar cáncer

a dios le gusta la salchicha

Es adicto al hojaldre

dios ha intentado ser vegano ir a meditar no comer animales respetarlos no juzgar saber que todo es ideología el sistema te divide pero hay una verdad y es cuántica nosotros tenemos a dios adentro somos caníbales pero lo hemos olvidado al nacer hemos olvidado que éramos un todo éramos luz éramos algo que no sufría éramos algo que flotaba Hemos olvidado

ahora queremos ayudar contribuir hacer servicio Amar a un gurú somos depresivos y somos latinoamericanos pero vivimos en Australia cuando vamos a un restaurante ordenamos comida sin productos animales conocemos nuestros traumas de infancia sabemos que tenemos dos ejes la carencia y la culpa sabemos que llamamos la atención somos víctimas muchos tenemos anorexia somos frágiles hemos sabido no querer la vida no querer nuestra vida" 
"dios quiere atravesar los ojos de tantos jueces que también anhelan ser publicados mientras queman la amazonia y jaurías de micos mueren ardidos hay que poder hacer avanzar el manuscrito encontrar la manera más extraña de ser poeta en el primer poema dios"

"las ideas son huevos prestos

a caer

pelotas para que los niños jueguen

hagan trampa

les tiren a los débiles del curso

flacos feos aterrados

un balonazo en la frente

vaga por las fincas las cercas invisibles

le pasan corrientazos en la espalda lame el lomo

pero no hay herida repasa

porque su saliva mata el tétano insiste

pero no hay herida 


\section{la palabra}

en las fincas nada se pudre

flores bajo plásticos

vacas encerradas en establos cuidadas por alarmas

unos pollos alumbrados en galpones

no hay infinito todo es parcela

\section{Referencias}

Nietzsche, F. (2002). La Gaya Ciencia. Madrid, España: Editorial Edaf.

Bataille, G. (1981). Madame Edwarda. Barcelona, España: Tusquets Editores.

Gauffreteau-Sévy. (1967). El último acto. En Hieronymus Bosch (pp. 195-198). Barcelona,

España: Editorial Labor.

Calvino, I. (1997). La filosofía de Raymond Queneau. En Por qué leer los clásicos (p. 256).

Barcelona, España: Tusquets Edit. 